\title{
ANALISIS TATA RUANG TEMPAT PENYIMPANAN DOKUMEN REKAM MEDIS PASIEN DITINJAU DARI ASPEK ANTROPOMETRI PETUGAS REKAM MEDIS
}

\author{
AnggyPramudhita Putri ${ }^{1}$, Endang Triyanti ${ }^{2}$, Dedi Setiadi ${ }^{3}$ \\ ${ }^{1}$ Staf RSU PELNI Jakarta, \\ ${ }^{2,3}$ Dosen Program Studi D III PIKES Poltekkes Kemenkes Tasikmalaya, Dosen Program Studi D III \\ PIKES Poltekkes Kemenkes Tasikmalaya \\ Email: Pramudhita.putri@yahoo.co.id, triyanti.endang@yahoo.co.id, Ded_set165@yahoo.co.id
}

\begin{abstract}
Background of research that filing officers have difficulty in taking medical record documents because of having to take this documents alternately in the same shelf. It caused by distance between the shelf which adjacent. Moreover, there are complaint stiff in hands and feet maybe discrepancy between layout with officers anthropometric. The purpose of this research is analyze of layout involve high, long and width of shelf, distance between shelf and wide of area reviewed from the anthropometric aspect of medical record officers involve the reach of hand to above, length of arm and width of shoulder. Design of this research is descriptive. Sample of this reseacrh is outpatient filing officers as much as 6 persons and taken by total sampling. Result of research for size of outpatient filing officers layout dr. Soekardjo General Region Hospital Tasikmalaya City which adapted with anthropometric data of outpatient filing officers are high of shelf $180 \mathrm{~cm}$ after adapted then size become 185,5 cm, long of shelf 229,5 become 142,5 cm, width of shelf $50 \mathrm{~cm}$ become $54 \mathrm{~cm}$, distance between shelf $63 \mathrm{~cm}$ become $102 \mathrm{~cm}$, wide of area 32,06 $\mathrm{m} 2$ after adapted become 35,69 $\mathrm{m} 2$. The result of size from measurement in dr. Soekardjo General Region Hospital Tasikmalaya City is smaller than size that got from measurement result. It can be analyzed that condition of room in dr. Soekardjo General Region Hospital Tasikmalaya City inadequate and inappropriate with size of body dimension outpatient filing officers. It will be better if condition of room was adapted with anthropometric data of outpatient filing officers, so officers feel more comfortable in doing his job.
\end{abstract}

Keywords : Layout, Medical Record Document Storage, Anthropometric of Medical Record Officers

\begin{abstract}
Abstrak
Penelitian ini bertujuan untuk menganalisis tata ruang meliputi tinggi rak, panjang rak, lebar rak, jarak antar rak dan luas ruangan ditinjau dari aspek antropometri petugas rekam medis meliputi jangkauan tangan ke atas, panjang depa dan lebar bahu. Jenis Penelitian yang digunakan bersifat deskriptif. Sampel penelitian ini ialah petugas filing rawat jalan sebanyak 6 orang yang diambil secara total sampling. Hasil penelitian ini adalah untuk ukuran tata ruang filing rawat jalan di RSUD dr. Soekardjo Kota Tasikmalaya yang disesuaikan dengan data antropometri petugas filing rawat jalan ialah tinggi rak $180 \mathrm{~cm}$ setelah disesuaikan maka ukuran menjadi 185,5 $\mathrm{cm}$, Panjang rak 229,5 cm disesuaikan menjadi 142,5 cm, Lebar rak $50 \mathrm{~cm}$ disesuaikan menjadi $54 \mathrm{~cm}$, Jarak antar rak $63 \mathrm{~cm}$ disesuaikan menjadi $102 \mathrm{~cm}$, luas ruangan 32,06 $\mathrm{m} 2$ setelah disesuaikan menjadi 35,69m2. Ukuran yang dihasilkan dari pengukuran di RSUD dr. Soekardjo Kota Tasikmalaya lebih kecil dibandingkan ukuran yang diperolah dari hasil perhitungan. Hal itu dapat dianalisis bahwa keadaan ruangan di RSUD dr. Soekardjo Kota Tasikmalaya kurang memadai dan belum sesuai dengan ukuran dimensi tubuh petugas filing rawat jalan. Alangkah baiknya apabila kondisi ruangan disesuaikan dengan data antropometri petugas filing rawat jalan sehingga petugas merasa lebih nyaman dalam melakukan pekerjaannya.
\end{abstract}

Kata kunci : Tata Ruang, Tempat Penyimpanan, Antropometri 


\section{PENDAHULUAN}

Berdasarkan Keputusan Menteri Kesehatan Nomor 377/Menkes/SK/III/2007 tentang Standar Profesi Perekam dan Informasi Kesehatan bahwa "Pembangunan kesehatan diarahkan untuk mewujudkan derajat kesehatan yang optimal. Untuk mencapai tujuan tersebut dibutuhkan upaya pengelolaan berbagai sumber daya, baik oleh pemerintah maupun masyarakat sehingga dapat tersedia pelayanan kesehatan yang efisien, bermutu dan terjangkau".

Setiap sarana pelayanan kesehatan diwajibkan menyelenggarakan rekam medis, salah satu manfaatnya sebagai bukti pelayanan kesehatan yang dilakukan di rumah sakit.Rekam medis merupakan catatan tertulis pasien yang termasuk pada golongan arsip vital. Dimana arsip vital menurut UndangUndang No.43 tahun 2009 tentang Kearsipan Bab I, Pasal 1 bahwa Arsip Vital adalah arsip yang keberadaannya merupakan persyaratan dasar bagi kelangsungan operasional pencipta arsip, tidak dapat diperbaharui, dan tidak tergantikan apabila rusak atau hilang dan sering disebut arsip kelas satu.

Menurut PerMenKes No.269 MENKES/PER/ III/2008 tentang Rekam Medis Bab III, pasal 7 bahwa sarana pelayanan kesehatan wajib menyediakan fasilitas yang diperlukan dalam rangka penyelenggaraan rekam medis. Rekam medis diselenggarakan oleh Unit Rekam Medis salah satunya yaitu filing yang merupakan media untuk penyimpanan dokumen rekam medis yang berfungsi sebagai penyimpanan, penyedia dan pelindung dokumen rekam medis.

Berdasarkan penjelasan di atas, unit rekam medis salah satunya filing memiliki peran dalam hal penyimpanan sampai perlindungan dokumen rekam medis. Penyimpanan dokumen rekam medis akan berjalan dengan baik apabila terdapat fasilitas yang menunjang yaitu rak penyimpanan dokumen rekam medis sehingga selain dokumen rekam medis tertata dengan baik hal ini juga dapat mempermudah dalam pengambilan dan penyimpanan dokumen rekam medis.

Terciptanya kemudahan petugas rekam medis dalam pengambilan serta penyimpanan Dokumen Rekam Medis didukung adanya tata ruang penyimpanan yang ergonomis sesuai dengan ukuran jangkauan dimensi tubuh manusia.Perancangan tempat kerja pada dasarnya merupakan suatu aplikasi data antropometri yang merupakan data ukuran dimensi tubuh manusia. Manusia pada dasarnya akan memiliki bentuk, ukuran (tinggi, lebar, dsb) berat dan lain-lain yang berbeda satu dengan yang lainnya. Anthropometri secara luas akan digunakan sebagai pertimbangan-pertimbangan ergonomis dalam memerlukan interaksi manusia. Data anthropometri yang berhasil diperoleh akan diaplikasikan secara luas. Data antropometriakan menentukan bentuk, ukuran dan dimensi yang tepat yang berkaitan dengan produk yang dirancang dan manusia yang akan mengoprasikan/menggunakan produk tersebut.

Rustiyanto, E dan Rahayu W.A (2011) menyatakan bahwa hal-hal yang harus diperhatikan di dalam ruangan penyimpanan dokumen rekam medis yaitu suhu, luas ruangan filing, jarak, aman, pencahayaan, debu, vector penyakit. Hal tersebut tentunya harus diperhatikan dikarenakan petugas akan bekerja secara terus menerus di tempat kerja, dengan tempat kerja yang nyaman serta ruang gerak petugas yang efisien maka kinerja petugas pun bisa optimal serta meminimalisir terjadinya kelelahan akibat kerja.

Berdasarkan studi pendahuluan dan pengalaman praktik lapangan pada semester 4 yang peneliti lakukan di RSUD dr. Soekardjo Kota Tasikmalaya, peneliti melihat pengelolaan rekam medis nya cukup baik, akan tetapi ada beberapa permasalah yaitu dokumen rekam medis yang disimpan di samping setiap rak penyimpanan dokumen rekam medis sehingga menyulitkan ruang gerak petugas karena space untuk lalu lalang yang dipenuhi oleh dokumendokumen ada disetiap sudutnya. Selain itu juga kesulitan dalam pengambilan dokumen rekam medis karena jarak antara rak yang satu dengan yang lainnya berdekatan sehingga petugas kesulitan melakukan pengambilan dan penyimpanan secara bersamaan di tempat yang sama (harus bergantian dalam melakukan pengambilan maupun penyimpanan dokumen rekam medis). Selain itu juga berdasarkan hasil wawancara kepada salah satu petugas di tempat penyimpanan dokumen rekam medis bahwa petugas sering mengalami pegal-pegal setiap setelah selesai melakukan tugas di Rumah Sakit.

Berdasarkan permasalahan diatas menjadi dasar pertimbangan peneliti untuk melakukan penelitian dengan judul "Analisis Tata Ruang Tempat Penyimpanan Dokumen Rekam Medis Pasien Ditinjau Dari Aspek Antropometri Petugas Rekam MedisDi RSUD dr. Soekardjo Kota Tasikmalaya Tahun 2014". 


\section{METODE}

Jenis penelitian yang digunakan adalah deskriptif (Azwar, 2001 dalam Siswanto, 2013) yaitu menganalisa dan menyajikan fakta secara sistematis sehingga dapat lebih mudah untuk di pahami dan disimpulkan.

Populasi penelitian ini adalah petugas yang berada di unit rekam medis terdapat 6 orang. Sampel dalam penelitian ini total populasi. Instrument Penelitian diantaranya adalah pedoman wawancara, alat perekam sebagai alat bantu dalam melakukan pengumpulan data, Lembar observasi untuk mencatat hasil pengukuran data antropometri petugas dan tata ruang penyimpanan dokumen rekam medis pasien, kalkulator sebagai alat untuk menghitung hasil pengukuran, meteran jahit untuk mengukur jangkauan tangan keatas, panjang depa, lebar bahu, meteran bangunan untuk mengukur panjang rak, lebar rak, tinggi rak, jarak rak dan luas ruangan.

Cara pengumpulan data dengan cara observasi bertujuan untuk mengamati tata ruang beserta antropometri petugas filingdi RSUD dr. Soekardjo Kota Tasikmalaya.

\section{HASIL}

Sistem penyimpanan dokumen rekam medis di RSUD dr. Soekardjo Kota Tasikmalaya yaitu desentralisasi yaitu sistem penyimpanan dengan cara memisahkan dokumen rekam medis rawat jalan dan rawat inap pada folder tersendiri dan ruangan tersendiri. Dokumen rekam medis pasien rawat jalan disimpan disatu tempat penyimpanan yaitu di bagian OPD (Out Patien Department), sedangkan dokumen rekam medis pasien rawat inap disimpan di unit rekam medis.

Sistem Penjajaran yang digunakan di RSUD dr. Soekardjo Kota Tasikmalaya berdasarkan dua angka tengah Middle Digit Filing (MDF) untuk Dokumen Rekam Medis (DRM) pasien Rawat Jalan. Penjajaran Middle Digit Filing (MDF) yaitu sistem penyimpanan dokumen rekam medis dengan cara menjajarkan dokumen rekam medis berdasarkan dua angka kelompok tengah pada rak penyimpanan. RSUD dr.Soekardjo Kota Tasikmalaya memiliki ruang Filing dengan jumlah 10 rak, tempat penyimpanan dokumen rekam medis menggunakan rak terbuka dengan dua muka yang masing-masing rak tersebut terdapat 6 sub rak.
Petugas yang melakukan pengambilan dan penyimpanan dokumen rekam medis sebanyak 6 orang dengan jenis kelamin laki-laki yang memiliki usia berbeda-beda. Petugas rekam medis bekerja dengan kondisi Ruangan tempat penyimpanan yang kurang memadai.Berikut merupakan gambar kondisi ruang penyimpanan dokumen rekam medis di RSUD dr.Soekardjo Kota Tasikmalaya.
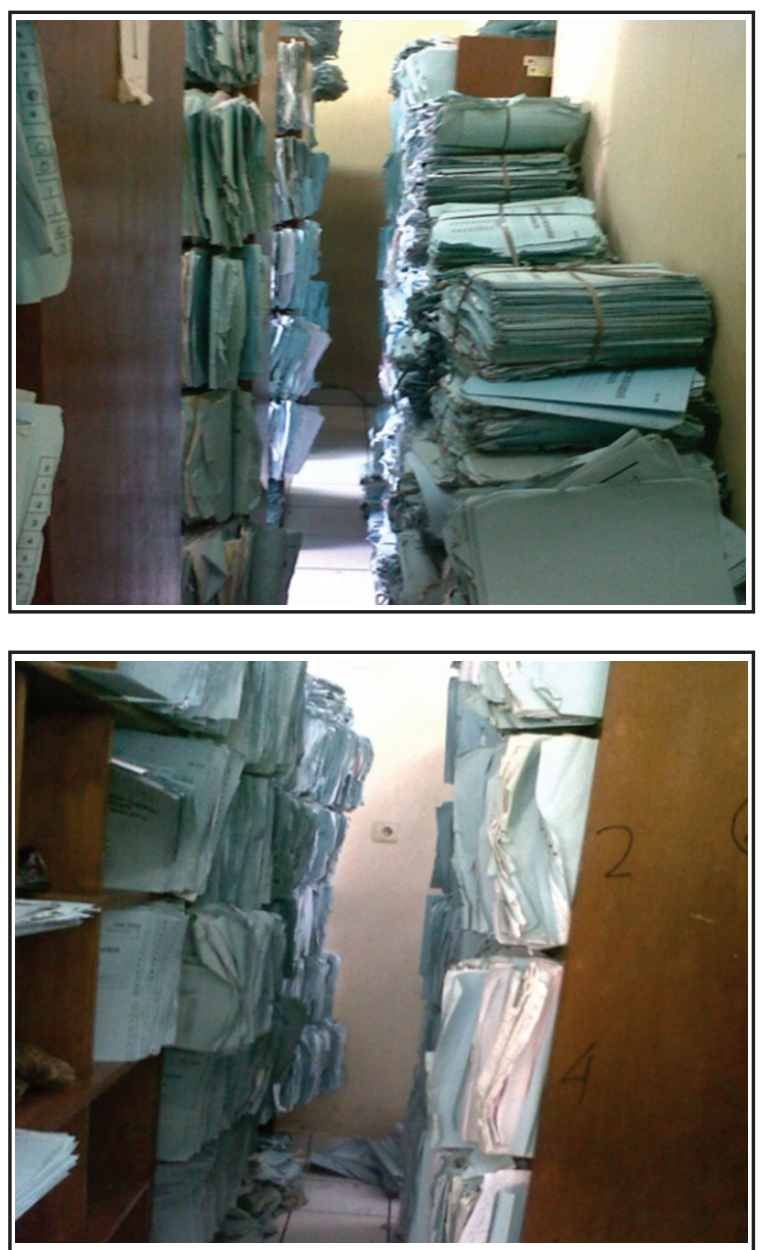

Gambar1 Keadaan Ruang Penyimpanan Dokumen Rekam Medis di RSUD dr. Soekardjo Kota Tasikmalaya

Dari gambar diatas terlihat bahwa tata ruang yang masih belum baik, banyak dokumen rekam medis yang disimpan di lantai tidak pada rak File, jarak antar rak yang begitu sempit, banyak kondisi dokumen rekam medis yang sudah sobek dikarenakan tersenggol petugas rekam medis saat melakukan pengambilan maupun penyimpanan, dokumen rekam medis yang tersimpan di rak dengan tidak rapi serta masih banyak dokumen rekam medis yang sengaja dipaksa dimasukan pada rak meskipun rak sudah penuh. 
Tata Ruang Tempat Penyimpanan Dokumen Rekam Medis Pasien Rawat Jalan

Berikut dibawah ini adalah gambar rak penyimpanan Dokumen Rekam Medis beserta ukurannya.

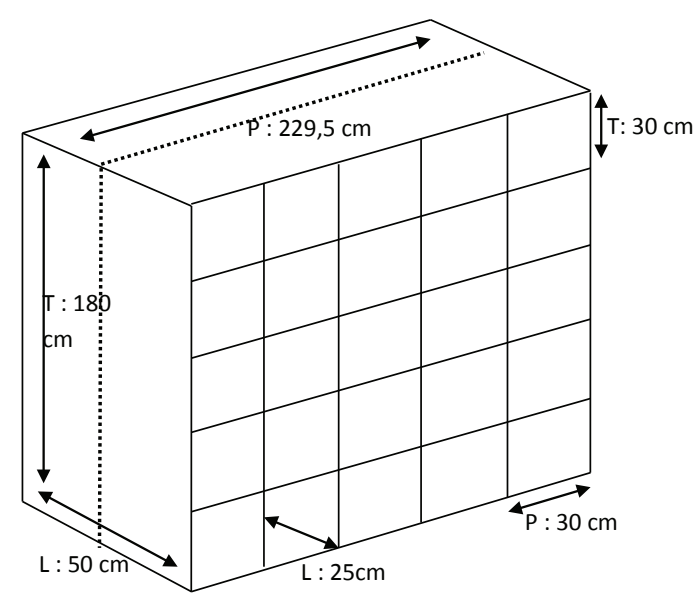

Gambar 2 Gambar dan Ukuran tempat penyimpanan dokumen rekam medis di RSUD dr. Soekardjo Kota Tasikmalaya

Berdasarkan gambar diatas dapat dilihat ukuranukuran rak penyimpanan dokumen rekam medis. Rak yang digunakan di filing RSUD dr. Soekardjo Kota Tasikmalaya terdapat 10 rak. Adapun Item-item yang dilakukan pengukuran terdiri dari sebagai berikut :

\section{Panjang rak}

Panjang rak tempat penyimpanan dokumen rekam medis terdiri dari dua macam ukuran. Ukuran rak yang pertama yaitu $279,5 \mathrm{~cm}$ terdiri dari 2 rak dan ukuran rak yang kedua yaitu 179,5 cm berjumlah 8 rak. Dikarenakan ukuran panjang rak yang berbeda-beda maka dilakukan perhitungan rata-rata dengan ukuran $229,5 \mathrm{~cm}$

2. Tinggi rak

Tinggi rak penyimpanan dokumen rekam medis seluruhnya memiliki ukuran yang sama yaitu $180 \mathrm{~cm}$. Setiap rak tempat penyimpanan dokumen rekam medis terdiri dari 6 tingkat.

3. Lebar rak

Lebar rak penyimpanan dokumen rekam medis dengan rak terbuka dua sisi seluruhnya berukuran $50 \mathrm{~cm}$ sehingga untuk ukuran setiap satu sisi memiliki lebar rak masing-masing berukuran $25 \mathrm{~cm}$. Ukuran dokumen rekam medis ialah dengan panjang $30 \mathrm{~cm}$ dan lebar $26 \mathrm{~cm}$.
4. Jarak Antar Rak

Jarak antar rak tempat penyimpanan dokumen rekam medis terdapat beberapa macam ukuran dari mulai $54 \mathrm{~cm}-74 \mathrm{~cm}$. Ukuran jarak antar rak berbeda-beda sehingga dilakukan perhitungan rata-rata jarak dan ditemukan hasil rata-rata jarak antar rak yaitu $63 \mathrm{~cm}$.

5. Luas ruangan

Berdasarkan hasil penelitian di lapangan, ruangan filing disatukan dengan ruang pendaftaram pasien rawat inap yang sekaligus sebagai ruang penjaminan pasien rawat inap. Akan tetapi berikut merupakan gambar ukuran ruangan filingnya saja.Dapat dilihat gambar 4.3 ruangan filing dihalaman berikutnya.

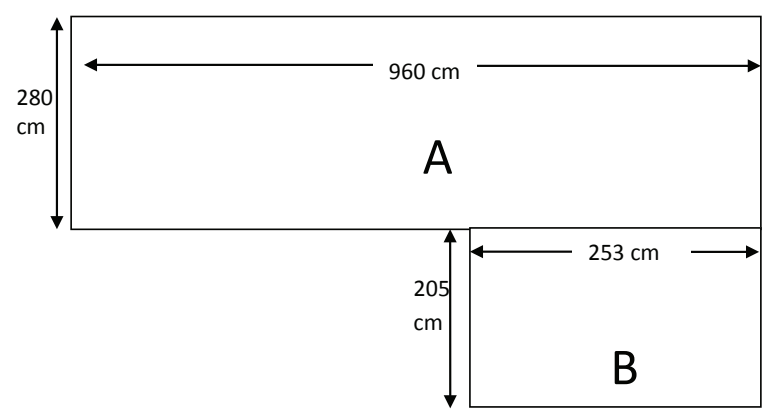

Gambar3 Gambar dan ukuran luas ruangan Filing Rawat Jalan di RSUD dr. Soekardjo Kota Tasikmalaya

Luas ruangan $\mathrm{A}=\mathrm{P} \times \mathrm{L}$

$$
\begin{aligned}
& =960 \times 280 \\
& =268.800 \mathrm{~cm}
\end{aligned}
$$

Luas ruangan $\mathrm{B}=\mathrm{P} \times \mathrm{L}$

$$
\begin{aligned}
& =253 \times 205 \\
& =51.865 \mathrm{~cm}
\end{aligned}
$$

Luas ruangan $\mathrm{A}+\mathrm{B}$

$$
\begin{aligned}
& =268.800+51.865 \\
& =320.665 \mathrm{~cm} \\
& =32,06 \mathrm{~m}^{2}
\end{aligned}
$$

Ruang tempat penyimpanan dokumen rekam medis berbentuk L. Untuk ukuran ruangan A memiliki ukuran dengan panjang $960 \mathrm{~cm}$ dan lebar $280 \mathrm{~cm}$ sedangkan untuk ukuran ruangan $\mathrm{B}$ memiliki ukuran panjang $253 \mathrm{~cm}$ dan lebar $205 \mathrm{~cm}$. Keseluruhan ukuran ruang tempat penyimpanan dokumen rekam medis yaitu $32,06 \mathrm{~m}^{2}$.

\section{Data Antropometri Petugas Rekam Medis Rawat Jalan.}

Antropometri merupakan pengukuran terhadap dimensi tubuh manusia dan dalam hal ini bagian 
tubuh yang dilakukan pengukuran ialah jangkauan tangan ke atas, lebar bahu dan panjang depa. Pengukuran ini dilakukan kepada 6 orang petugas pengambilan dan penyimpanan dokumen rekam medis pasien rawat jalan.

Berikut dibawah ini ialah hasil pengukuran dimensi tubuh terhadap petugas rekam medis di RSUD dr.Soekardjo Kota Tasikmalaya.

Tabel 1 Data Antropometri Petugas Rekam Medisdi RSUD dr.Soekardjo Kota Tasikmalaya

\begin{tabular}{cccc}
\hline \multicolumn{4}{c}{ Data yang Diukur (cm) } \\
\hline No & $\begin{array}{c}\text { JangkauanTangan } \\
\text { Keatas(Jtk) }\end{array}$ & $\begin{array}{c}\text { Panjang } \\
\text { Depa(Pd) }\end{array}$ & $\begin{array}{c}\text { Lebar } \\
\text { Bahu(Lb) }\end{array}$ \\
\hline 1 & 204 & 164 & 44 \\
\hline 2 & 198 & 154 & 40 \\
\hline 3 & 216 & 168 & 51 \\
\hline 4 & 198 & 154 & 40 \\
\hline 5 & 216 & 179 & 48 \\
\hline 6 & 186 & 145 & 37 \\
\hline Jml & 1218 & 964 & 260 \\
\hline
\end{tabular}

Berdasarkan tabel diatas terdapat 6 (enam) ukuran dimensi tubuh manusia dengan ukuran yang berbeda-beda. Perbedaan ukuran dimensi tubuh petugas rekam medis dari mulai ukuran tertinggi sampai ukuran dimensi tubuh terendah. Ukuranukuran tersebut terdapat ukuran jangkauan tangan keatas petugas yang tertinggi ialah $216 \mathrm{~cm}$, panjang depa $179 \mathrm{~cm}$ dan lebar bahu dengan ukuran $51 \mathrm{~cm}$. Sedangkan ukuran dimensi tubuh petugas terendah untuk jangkauan tangan keatas ialah $186 \mathrm{~cm}$, panjang depa $145 \mathrm{~cm}$ dan lebar bahu $37 \mathrm{~cm}$.

Analisis tata ruang tempat penyimpanan dokumen rekam medis pasien ditinjau dari aspek antropometri petugas rekam medis di RSUD dr. Soekardjo Kota Tasikmalaya

Pengolahan data antropometri dan hasil pengukuran tata ruang ini dilakukan perhitungan secara manual, dengan menggunakan teknik statistika yang mencari nilai rata-rata berdasarkan hasil pengukuran setiap dimensi tubuh yang digunakan untuk analisis tata ruang tempat penyimpanan dokumen rekam medis yaitu rak Filing. Setiap orang tentunya akan memiliki ukuran dimensi tubuh manusia yang berbeda-beda, berikut dibawah ini merupakan hasil pengukuran dimensi tubuh manusia petugas di RSUD dr. Soekardjo Kota Tasikmalaya.
Tabel 2 Data antropometri untuk pengolahan dalam perhitungan tata ruang yang ideal berdasarkan dimensi tubuh manusia

\begin{tabular}{cccccc}
\hline \multicolumn{6}{c}{ Data yang Diukur (cm) } \\
\hline $\begin{array}{c}\text { Jangkauan } \\
\begin{array}{c}\text { Tangan } \\
\text { Keatas } \\
\text { (Jtk) }\end{array}\end{array}$ & $\begin{array}{c}\text { Hasil } \\
\text { kuadrat }\end{array}$ & $\begin{array}{c}\text { Panjang } \\
\text { Depa } \\
\text { (Pd) }\end{array}$ & $\begin{array}{c}\text { Hasil } \\
\text { kuadrat }\end{array}$ & $\begin{array}{c}\text { Lebar } \\
\text { Bahu } \\
\text { (Lb) }\end{array}$ & $\begin{array}{c}\text { Hasil } \\
\text { kuadrat }\end{array}$ \\
\hline 204 & 41646 & 164 & 26896 & 44 & 1936 \\
\hline 198 & 39204 & 154 & 23716 & 40 & 1600 \\
\hline 216 & 46656 & 168 & 28224 & 51 & 2601 \\
\hline 198 & 39204 & 154 & 23716 & 40 & 1600 \\
\hline 216 & 46656 & 179 & 32041 & 48 & 2304 \\
\hline 186 & 34596 & 145 & 21025 & 37 & 1369 \\
\hline 1218 & 247932 & 964 & 155618 & 260 & 11410 \\
\hline
\end{tabular}

Berdasarkan hasil pengukuran antropometri petugas rekam medis kemudian dari data tersebut dilakukan perhitungan. Berikut merupakan perhitungan dimensi rak Filing yang dilakukan berdasarkan data antropometri jangkauan tangan keatas, panjang depan dan lebar bahu.

a. Data jangkauan tangan ke atas digunakan untuk acuan ukuran tinggi rak tempat penyimpanan dokumen rekam medis.

1) Mean

$$
\begin{aligned}
& \text { rata }- \text { rata }(\bar{x})=\frac{\sum x}{n} \\
& x=1218 \\
& x=203 \mathrm{~cm}
\end{aligned}
$$

2) Standar Deviasi

$$
\begin{aligned}
S D & =\frac{1}{n} \sqrt{n\left(\sum\left(x^{2}\right)-\left(\sum x\right)^{2}\right.} \\
& =\frac{1}{6} \sqrt{6(247932)-(1218)^{2}} \\
& =\frac{1}{6} \sqrt{1.487 .592-1.483 .524} \\
& =\frac{1}{6} \sqrt{4068} \\
& =\frac{1}{6} x 63,78 \\
& =10,6
\end{aligned}
$$

3) Persentil ke 5

$$
\begin{aligned}
& \bar{x}-1,645 \sigma \\
& =203-1,645(10,6) \\
& =203-17,437 \\
& =185,5 \mathrm{~cm}
\end{aligned}
$$

Jadi tinggi rak yang sesuai dengan ukuran antropometri petugas ialah $185,5 \mathrm{~cm}$. 
b. Data panjang depa digunakan untuk acuan ukuran panjang rak tempat penyimpanan dokumen rekam medis.

c. Berikut ini ialah perbandingan antara hasil pengukuran rak di RSUD dr. Soekardjo Kota Tasikmalaya dan perhitungan

Tabel 3 Perbandingan hasil pengamatan dan perhitungan rak penyimpanan dokumen rekam medis

\begin{tabular}{lcc}
\hline Kriteria & $\begin{array}{r}\text { Hasil Pengamatan } \\
(\mathbf{c m})\end{array}$ & $\begin{array}{c}\text { Hasil Perhitungan } \\
(\mathbf{c m})\end{array}$ \\
\hline Tinggi Rak & 180 & 185,5 \\
Panjang Rak & 229,5 & 142,5 \\
Jarak antar rak & 63 & 70,8 \\
\hline
\end{tabular}

\section{PEMBAHASAN}

Filing Pasien Rawat Jalan di RSUD dr. Soekardjo Kota Tasikmalaya

Berdasarkan hasil wawancara kepada petugas filing di RSUD dr. Soekardjo Kota Tasikmalaya mengatakan di Rumah Sakit terdapat Standar Operasional Prosedur (SOP) dengan nomor 003/CM/2010 mengenai fasilitas dan peralatan. Salah satu kebijakan dalam SOP tersebut ialah adanya ruang kerja untuk staf yang memadai sehingga dapat mengelola rekam medis dengan baik, adanya ruang penyimpanan dokumen rekam medis baik untuk dokumen aktif dan non aktif serta terjamin keamananya.Akan tetapi kenyataan dilapangan mengenai ruang kerja staf masih kurang memadai dikarenakan ruangan tempat penyimpanan dokumen rekam medis masih belum efektif.Tata ruang rak penyimpanan dokumen rekam medis yang masih tidak beraturan dengan jarak yang berbeda-beda.Hal ini ditegaskan dengan pernyataan petugas yang mengatakan masih mengeluhkan mengenai kondisi ruang kerja mereka.

Petugas rekam medis sering mengeluhkan mengenai tempat penyimpanan dokumen rekam medis, dimulai dari jarak antar rak penyimpanan dokumen rekam medis yang sangat sempit.Ukuran panjang rak penyimpan dokumen rekam medis yang tidak seukuran serta kondisi ruangan filing yang kurang nyaman.

\section{Tata Ruang Tempat Penyimpanan Dokumen} Rekam Medis Pasien Rawat Jalan

Apabila ukuran tinggi rak ingin disesuaikan dengan ukuran data antropometri orang Indonesia secara keseluruhan maka ukuran jangkauan tangan keatas yang digunakan untuk tinggi rak ialah 202,1 cm.

\section{a. Panjang rak}

Panjang rak di filing RSUD dr. Soekardjo Kota Tasikmalaya ialah 229,5 cm, panjang rak tersebut sudah cukup ergonomis apabila melihat dari sisi pandang ukuran banyaknya sub rak yang ada dengan banyaknya dokumen dalam satu sub rak. Apabila disesuaikan dengan ukuran antropometri petugas maka untuk panjang rak tersebut idealnya dengan dengan ukuran $142,5 \mathrm{~cm}$ sehingga untuk jarak jangkauan pengambilan dokumen rekam medis di bagian arah kanan dan kiri terjangkau.

\section{b. Lebar rak}

Lebar rak penyimpanan di filing RSUD dr. Soekardjo Kota Tasikmalaya berukuran $50 \mathrm{~cm}$ dengan 2 muka, berarti lebar 1 muka rak masingmasing berukuran $25 \mathrm{~cm}$. Ukuran lebar rak sebaiknya disesuaikan dengan ukuran dimensi dokumen rekam medis, dimensi dokumen di RSUD dr. Soekardjo Kota Tasikmalaya memiliki ukuran dengan panjang $30 \mathrm{~cm}$ dan lebar $26 \mathrm{~cm}$. Hal ini menunjukan bahwa ukuran lebar rak dan lebar dokumen sudah efektif, tetapi pada sub rak tidak ada ruang expantionuntuk penambahan formulir pada setiap dokumen rekam medis sehingga sub rak menjadi penuh dan padat. Hal ini menyebabkan dokumen rekam medis keluar melebihi batas lebar ukuran rak.Ruang expantion merupakan ruang untuk penambahan ketebalan dokumen rekam medis. Hal ini itu dapat terjadi karena sistem penomoran yang dilakukan di RSUD dr. Soekardjo Kota Tasikmalaya menggunkanUnit Numbering System (UNS). UNS merupakan suatu sistem penomoran dimana sistem ini memberikan satu nomor rekam medis pada pasien berobat jalan maupun pasien rawat inap dan gawat darurat serta bayi baru lahir. Ini menyebabkan semakin banyak satu pasien datang berobat maka dokumen rekam medisnya semakin tebal. 


\section{c. Jarak antar rak}

Jarak antar rak penyimpanan dokumen rekam medis di RSUD dr. Soekardjo Kota Tasikmalaya memiliki ukuran berbeda-beda. Menurut Depkes 2006 bahwa jarak antara 2 (dua) buah rak untuk lalu lalang dianjurkan selebar $90 \mathrm{~cm}$ sedangkan berdasarkan hasil perhitungan rata-rata jarak antar rak yang ada di RSUD dr. Soekardjo Kota Tasikmalaya selebar $63 \mathrm{~cm}$. Maka untuk ukuran jarak antar rak tersebut tidak ergonomi, apabila ukuran jarak tersebut disesuaikan dengan antropometri petugas rekam medis maka didapatkan ukuran $102 \mathrm{~cm}$. Ukuran tersebut diperoleh dari hasil perhitungan $2 \times$ hasil persentil lebar bahu petugas yaitu $2 \times 51=102 \mathrm{~cm}$ atau disesuaikan dengan teori Wignjosoebroto dalam Nurrido (2009) yaitu $2 \times$ lebar bahu yaitu $2 \times 39,5=$ $79,2 \mathrm{~cm}$.

Berdasarkan hasil wawancara kepada petugas rekam medis, dengan ukuran jarak antar rak yang ada di RSUD dr. Soekardjo Kota Tasikmalaya saat ini menyebabkan kesulitan dalam pengambilan dokumen rekam medis dikarenakan petugas harus bergantian dalam melakukan pengambilan dokumen rekam medis pada tempat yang sama. Sehingga terjadinya keterlambatan dalam penyediaan dokumen rekam medis terhadap pasien.Pengukuran jarak antar rak File berguna untuk mempermudah dalam lalu lalang petugas rekam medis dalam melakukan pengambilan maupun penyimpanan dokumen rekam medis secara bersamaan tanpa mengalami hambatan.

\section{d. Luas ruangan}

Luas ruangan merupakan hasil perhitungan dari panjang dikalikan lebar ruangan. Berikut dibawah ini ialah ukuran luas ruangan yang disesuaikan dengan data antropometri petugas rekam medis di RSUD dr. Soekardjo Kota Tasikmalaya.

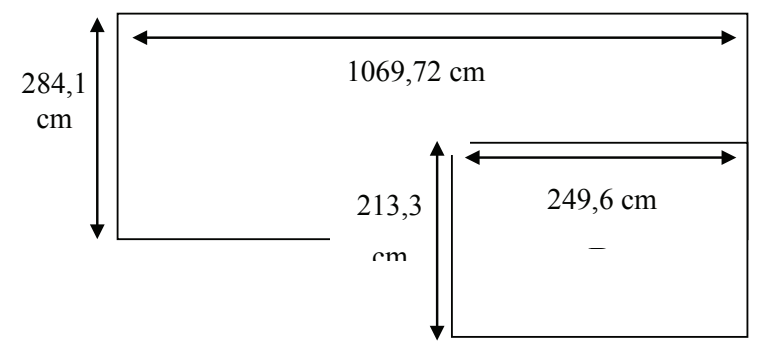

Gambar 4 Gambar dan ukuran luas ruangan berdasarkan perhitungan data antropometri petugas rekam medis di RSUD dr. Soekardjo Kota Tasikmalaya

Berikut dibawah ini merupakan ukuran luas ruangan yang disesuaikan dengan antropometri orang Indonesia.

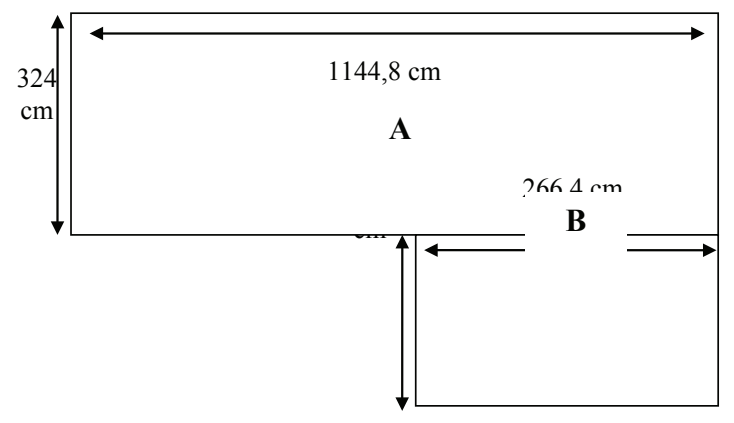

Gambar 5 Ukuran luas ruangan berdasarkan perhitungan data antropometri rata-rata orang Indonesia

Setelah dilakukan pengukuran jarak antar rak serta lebar rak di RSUD dr. Soekardjo Kota Tasikmalaya maka ditemukan ukuran luas ruangan sebesar 32,06 $\mathrm{m}^{2}$. Berdasarkan hasil perhitungan data antropometri petugas rekam medis yang dilakukan untuk luas ruangan yang diperlukan ialah dengan ukuran 35,69 $\mathrm{m}^{2}$. Apabila rak penyimpanan disesuaikan dengan data antropometri (jangkauan tangan keatas, panjang depa dan lebar bahu) rata-rata orang Indonesia maka luas ruangan yang dibutuhkan dan disediakan ialah dengan ukuran $43,61 \mathrm{~m}^{2}$.

\section{Data Antropometri Petugas Rekam Medis Rawat Jalan}

Berikut ini merupakan perbandingan ukuran tata ruang di rumah sakit dengan hasil perhitungan dan data antropometri orang Indonesia.

Tabel 4 Perbandingan ukuran tata ruang di rumah sakit dengan hasil perhitungan dan data antropometri orang Indonesia

\begin{tabular}{|c|c|c|c|c|}
\hline \multirow[t]{2}{*}{ Dimensi } & \multicolumn{2}{|c|}{$\begin{array}{c}\text { Perbandingan } \\
\text { Ukuran Tata } \\
\text { Ruang berdasarkan } \\
\text { Antropometri Petugas } \\
\text { Rekam Medis } \\
\end{array}$} & \multicolumn{2}{|c|}{$\begin{array}{c}\text { Perbandingan } \\
\text { Ukuran Berdasarkan } \\
\text { Antropometri Orang } \\
\text { Indonesia } \\
\end{array}$} \\
\hline & $\begin{array}{c}\text { Rumah } \\
\text { Sakit }\end{array}$ & Perhitungan & $\begin{array}{c}\text { Rumah } \\
\text { Sakit }\end{array}$ & $\begin{array}{c}\text { Data } \\
\text { Antropometri }\end{array}$ \\
\hline Tinggi rak & $180 \mathrm{~cm}$ & $185,5 \mathrm{~cm}$ & $180 \mathrm{~cm}$ & $202,1 \mathrm{~cm}$ \\
\hline
\end{tabular}




\begin{tabular}{|c|c|c|c|c|}
\hline \multirow[t]{2}{*}{ Dimensi } & \multicolumn{2}{|c|}{$\begin{array}{c}\text { Perbandingan } \\
\text { Ukuran Tata } \\
\text { Ruang berdasarkan } \\
\text { Antropometri Petugas } \\
\text { Rekam Medis } \\
\end{array}$} & \multicolumn{2}{|c|}{$\begin{array}{c}\text { Perbandingan } \\
\text { Ukuran Berdasarkan } \\
\text { Antropometri Orang } \\
\text { Indonesia }\end{array}$} \\
\hline & $\begin{array}{c}\text { Rumah } \\
\text { Sakit }\end{array}$ & Perhitungan & $\begin{array}{c}\text { Rumah } \\
\text { Sakit }\end{array}$ & $\begin{array}{c}\text { Data } \\
\text { Antropometri }\end{array}$ \\
\hline $\begin{array}{l}\text { Panjang } \\
\text { rak }\end{array}$ & $229,5 \mathrm{~cm}$ & $142,5 \mathrm{~cm}$ & $229,5 \mathrm{~cm}$ & $165,6 \mathrm{~cm}$ \\
\hline Lebar rak & $50 \mathrm{~cm}$ & $54 \mathrm{~cm}$ & $50 \mathrm{~cm}$ & - \\
\hline $\begin{array}{l}\text { Jarak } \\
\text { Antar } \\
\text { Rak }\end{array}$ & $63 \mathrm{~cm}$ & $102 \mathrm{~cm}$ & $63 \mathrm{~cm}$ & $79,2 \mathrm{~cm}$ \\
\hline $\begin{array}{l}\text { Luas } \\
\text { ruangan }\end{array}$ & $\begin{array}{l}32,06 \\
\mathrm{~m} 2\end{array}$ & $35,69 \mathrm{~m}^{2}$ & $32,06 \mathrm{~m}^{2}$ & $43,61 \mathrm{~m}^{2}$ \\
\hline
\end{tabular}

Tabel diatas merupakan ukuran tata ruang yang disesuaikan dengan data antropometri petugas rekam medis di RSUD dr. Soekardjo Kota Tasikmalaya dan anjuran berdasarkan teori Wignjosoebroto dalam penelitian Nurrido tentang ukuran antropometri orang Indonesia.

\section{SIMPULAN}

Berdasarkan hasil penelitian dan pembahasan yang telah disampaikan pada bab sebelumnya, maka simpulan yang dapat penulis sampaikan diantaranya adalah :

1. Ruangan filing di RSUD dr. Soekardjo Kota Tasikmalaya memiliki tata ruang yang kurang efektif. Ruangan filing Rawat Jalan memiliki 10 rak penyimpanan dokumen rekam medis. Berdasarkan hasil penelitian yang dilakukan untuk ukuran panjang rak semua sama akan tetapi sebelumnya petugas rekam medis pernah menambahkan 2 rak baru yang disimpan disatukan berdampingan sehingga tata ruang yang ada menjadi semakin sempit. Ukuran panjang rak di RSUD dr. Soekardjo Kota Tasikmalaya berbeda-beda, 2 rak yang memiliki ukuran $279,5 \mathrm{~cm}$ dan 8 rak memiliki 179,5 $\mathrm{cm}$. Jarak antar rak berbeda-beda sehingga dilakukan perhitungan hasil rata-rata untuk mempermudah perbandingan kesesuaian tata ruang. Ukuran rak tempat penyimpanan dokumen rekam medis berdasarkan hasil pengukuran ialah tinggi rak $180 \mathrm{~cm}$; panjang rak $229,5 \mathrm{~cm}$; lebar rak $50 \mathrm{~cm}$; rata-rata jarak antar rak yaitu $63 \mathrm{~cm}$; dan luas ruangan 32,06 $\mathrm{m}^{2}$.

2. Alat yang digunakan tentunya disesuaikan dengan penggunanya dan ukuran yang dibutuhkan untuk perancangan alat kerja menggunakan data antropometri petugas filing diRSUD dr. Soekardjo Kota Tasikmalaya. Dimensi tubuh manusia yang digunakan ialah jangkauan tangan keatas, panjang depa serta lebar bahu petugas rekam medis. Ukuran ratarata dari masing-masing dimensi tubuh manusia yaitu jangkauan tangan keatas $203 \mathrm{~cm}$, panjang depa 160,6 cm, lebar bahu $43,3 \mathrm{~cm}$.

Berdasarkan hasil pengukuran di RSUD dr. Soekardjo Kota Tasikmalaya dengan perhitungan data antropometri petugas dapat terlihat perbandinganya. Baik berupa penambahan ukuran maupun pengurangan ukuran terhadap alat yang digunakan. Ukuran yang dihasilkan dari pengukuran di RSUD dr. Soekardjo Kota Tasikmalaya lebih kecil dibandingkan ukuran yang diperolah dari hasil perhitungan maupun yang disesuaikan dengan teori Wignjosoebroto. Hal itu tentunya dapat di analisis bahwa keadaan ruangan di RSUD dr. Soekardjo Kota Tasikmalaya kurang memadai.

Ukuran perbaikan tata ruang untuk filing RSUD dr. Soekardjo Kota Tasikmalaya ialah untuk tinggi rak penambahan ukuran $5,5 \mathrm{~cm}$, panjang rak ada pengurangan ukuran yaitu $87 \mathrm{~cm}$, lebar rak penambahan ukuran $4 \mathrm{~cm}$, jarak antar rak penambahan ukuran $39 \mathrm{~cm}$, luas ruangan sebelumnya $32,06 \mathrm{~m}^{2}$ diperbaiki kebutuhan ukuran ruangan menjadi $35,69 \mathrm{~m}^{2}$.

\section{DAFTAR PUSTAKA}

Abidin, Y (2010). Kemampuan Menulis dan Berbicara Akademik. Edisi Revisi. Bandung: Rizqi Press.

Budi.S.C (2011).Manajemen Unit Kerja Rekam Medis. Yogyakarta: Quantum Sinergis Media.

Depkes RI. (2006). Pedoman Penyelenggaraan dan Prosedur Rekam Medis Rumah Sakit. Jakarta: Direktorat Jendral Bina Pelayanan Medik.

Dirjen Yanmed No.78/Yanmed/RS.Umdik/ YMU/I/1991 tentang rekam medis.

Hatta, G (2013). Pedoman Manajemen Informasi Kesehatan di Sarana Pelayanan Kesehatan. Jakarta: Universitas Indonesia (UI-Press). 
Indarwati (2006).Kesesuaian Desain Rak File Ditinjau Dari Aspek Antrhopometri, Dimensi dan Sis tern Penjajaran Dokumen Rekam Medis di Bagian Filing RS PKU Muhammadiyah Surakarta tahun 2006. Karya Tulis llmiah APIKES Bhakti Mulia. AP1KES Surakarta: tidak diterbitkan.

Keputusan Menteri Kesehatan NO.377/Menkes/SK/ III/2007 tentang Standar Profesi Perekam dan Informasi Kesehatan.

Noor.J. (2010).Metodologi Penelitian. Jakarta: Kencana.

Notoatmodjo, S (2010). Metodologi Penelitian Kesehatan. Jakarta: Rineka Cipta

Nuraida, I (2008).Manajemen Administrasi Perkantoran. Yogyakarta: Kanisius

Nurmianto, E (2008). Ergonomi Konsep Dasar dan Aplikasinya. Edisi Kedua. Surabaya: Guna Widya.

Nurnovitasari, N (2011). Analisis Penataan Ruang Kantor Tata Usaha dalam Mencapai Efisiensi Kerja Pegawai.Skripsi.Fakultas Keguruan dan Ilmu Pendidikan. Universitas Sebelas Maret Surakarta: Tidak diterbitkan.
Nurridho, 1.A. (2009, Qktober). Prediksi Kebutuhan Rak Penyimpanan Dokumen Rekam Medis Aktif di Bagian Filing Rumah Sakit Umum Daerah Kabupaten Sragen.Jurnal Kesehatan, 3 (2).80-101. Pebruari 18.2014. http://eiurnal. mithus.ac.id/index.nhp/rm/article/view/5/3.

Panero, J. dan Zelnik, M. (2003). Dimensi Manusia dan Ruang Interior Buku Panduan Untuk Standar Pedoman Perancangan. Jakarta: Erlangga.

Peraturan Menteri Kesehatan Nomor 269/MENKES/ PER/III/2008 Tentang Rekam Medis.

Rustiyanto, E. dan Rahayu, W.A. (2011).Manajemen Filing Dokumen Rekam Medis dan Informasi Kesehatan. Yogyakarta: Politeknik Kesehatan Permata Indonesia.

Santoso, G (2013). Ergonomi Terapan. Jakarta: Prestasi Pustaka Publisher.

Saryono dan Anggraeni, M.D (2013).Metodologi Penelitian Kualilatif dan Kuantitatif Dalam Bidan Kesehatan. Jakarta: NuhaMedika.

Sugiyono.(2008). Statistika Untuk Penelitian. Bandung : CV Alfabeta.

Undang-Undang No.43 Tahun 2009 Tentang Kearsipan. 